\title{
2. STRUCTURAL FRAMEWORK OF THE ODP LEG 131 AREA, NANKAI TROUGH ${ }^{1}$
}

\author{
G. F. Moore, ${ }^{2}$ D. E. Karig,${ }^{3}$ T. H. Shipley, ${ }^{4}$ A. Taira,${ }^{5}$ P. L. Stoffa,${ }^{4}$ and W. T. Wood ${ }^{4}$
}

\begin{abstract}
A reprocessed multichannel seismic reflection line across the ODP Leg 131 area allows well-controlled structural interpretations of the accretionary prism toe. A $2.5-\mathrm{km}$-wide protothrust zone is characterized by thickening and seaward tilting of the trench wedge strata, associated with a significant amount of layer-parallel shortening and fluid expulsion. The frontal thrust is imaged as a fault-plane reflection and ramps upward from a décollement within the Shikoku Basin hemipelagic section. Over this ramp, the overthrusting sediments form a fault-bend fold on which ODP Site 808 is located. The spacing of the first three thrusts at the toe of the prism is approximately $1.5-1.7 \mathrm{~km}$. Thrust spacing decreases arcward to less than $1 \mathrm{~km}$ as horizontal shortening progresses. The polarity of the reflection marking the basal décollement is reversed under the trench and accretionary prism. This polarity reversal is generated by a zone of low velocity beneath the décollement, indicating that the subducting basin hemipelagic section has not dewatered to the extent that the section above has, and therefore may be overpressured.
\end{abstract}

\section{INTRODUCTION}

The purpose of this paper is to define the framework of deformation in the Leg 131 area on the basis of seismic reflection profiles and two-ship seismic velocity data. We present a depthmigrated seismic reflection profile that allows detailed interpretation of the geometry of the frontal thrust region drilled on Leg 131. We also interpret the deformational processes active in the protothrust zone and at the décollement. Velocity data collected during a two-ship survey provide constraints on the reduction of porosity during deformation. We will restrict most of our discussion to the area seaward of the third thrust packet because this area was the focus of Leg 131 drilling and because our velocity control is best in this area. See Moore et al. (1990) for a more regional discussion of our seismic data in the central Nankai Trough area.

\section{DATA ACQUISITION, PROCESSING AND INTERPRETATION}

The seismic reflection data presented here were collected on the Fred Moore and the Tansei Maru in 1987 as part of a regional study in support of ODP drilling (Fig. 1). Line NT62-8 was collected with a 68 -channel, 33.3-m group interval streamer. The seismic source was a tuned array of six air guns totaling $16.9 \mathrm{~L}$ (1024 in. $\left.{ }^{3}\right)$. Initial processing included stacking, finite-difference time migration and depth conversion (see Moore et al., 1990 for details of the data acquisition and processing). The line was subsequently depth migrated (Backpocket Fig. 2 and Fig. 3) using the new split-step method described by Stoffa et al. (1990). Velocities for the depth migration were derived from two-ship split-spread profiles run parallel to the structural strike (Fig. 1), which were collected using two 6.6-L (400 in. $\left.{ }^{3}\right)$ water guns and a 96-channel,

\footnotetext{
${ }^{1}$ Taira, A., Hill, I., Firth, J., et al., 1991. Proc. ODP, Init. Repts., 131: College Station, TX (Ocean Drilling Program).

2 Department of Geology and Geophysics, University of Hawaii, 2525 Correa Road, Honolulu HI 96822.

${ }^{3}$ Department of Geological Sciences, Cornell University, Ithaca, NY 14853.

4 Institute for Geophysics, University of Texas, 8701 Mopac Boulevard, Austin, TX 79759.

${ }^{5}$ Ocean Research Institute, University of Tokyo, 1-15-1 Minamidai, Nakano-ku, Tokyo 164, Japan.
}

16.67-m group interval streamer (Wood, 1989; Stoffa et al., in press). Post stack spiking deconvolution sharpened the source signature to improve detailed interpretations.

Our interpretation was carried out on a workstation that allowed displays with various color schemes that accented reflections such as thrust faults and the décollement. Plots of seismic attributes (such as instantaneous phase and frequency) facilitated detailed correlations through complex regions. Interactive horizon flattening and fault restoration allowed more confident correlations across faults than was previously possible.

\section{SEISMIC STRATIGRAPHY}

The oceanic crust reflection in the Leg 131 area is unusually smooth and continuous (Backpocket Fig. 2 and Fig. 3), probably indicating that the basal $47-\mathrm{m}$-thick section of ash deposits drilled at Site 808 is regionally continuous and redistributed by currents, smoothing out the original oceanic crust topography. The Shikoku Basin sedimentary sequence overlies oceanic crust. The dominant lithology of the Shikoku Basin sequence at Site 808 was gray hemipelagic mud (Site 808 chapter, this volume). At Site 808 a lithologic break was defined between an upper, ash-rich unit and a lower, ash-poor unit at about 824 mbsf. We also recognize a seismic-stratigraphic subdivision between an upper and a lower unit (Figs. 3 and 4). These seismic-stratigraphic units, described below and referred to as the upper and lower Shikoku Basin sequences, do not correspond exactly to the similarly named lithostratigraphic units described at Site 808 (Site 808 chapter, this volume). The lower Shikoku Basin sequence is approximately $250-275 \mathrm{~m}$ thick. It is nearly acoustically transparent, but there are some low-amplitude internal reflections that are laterally continuous over several kilometers (Figs. 3 and 4). This lower unit is overlain by a 500 -m-thick layered unit that is acoustically poorly organized, exhibiting numerous discontinuous and wavy reflections (Fig. 4). Although some of the local discontinuities are due to structural deformation (e.g., faults at common midpoint (CMP) 685-730), much of the apparent disruption may reflect original sedimentary relations. Some reflection truncations (e.g., CMP 520-640, 5200-5400 $\mathrm{m})$ may be caused by migration of channels on the Shikoku Basin floor seaward of the trench (Fig. 4).

A trench sediment wedge overlies the Shikoku Basin sequence (Figs. 3 and 4). The trench wedge strata onlap the 


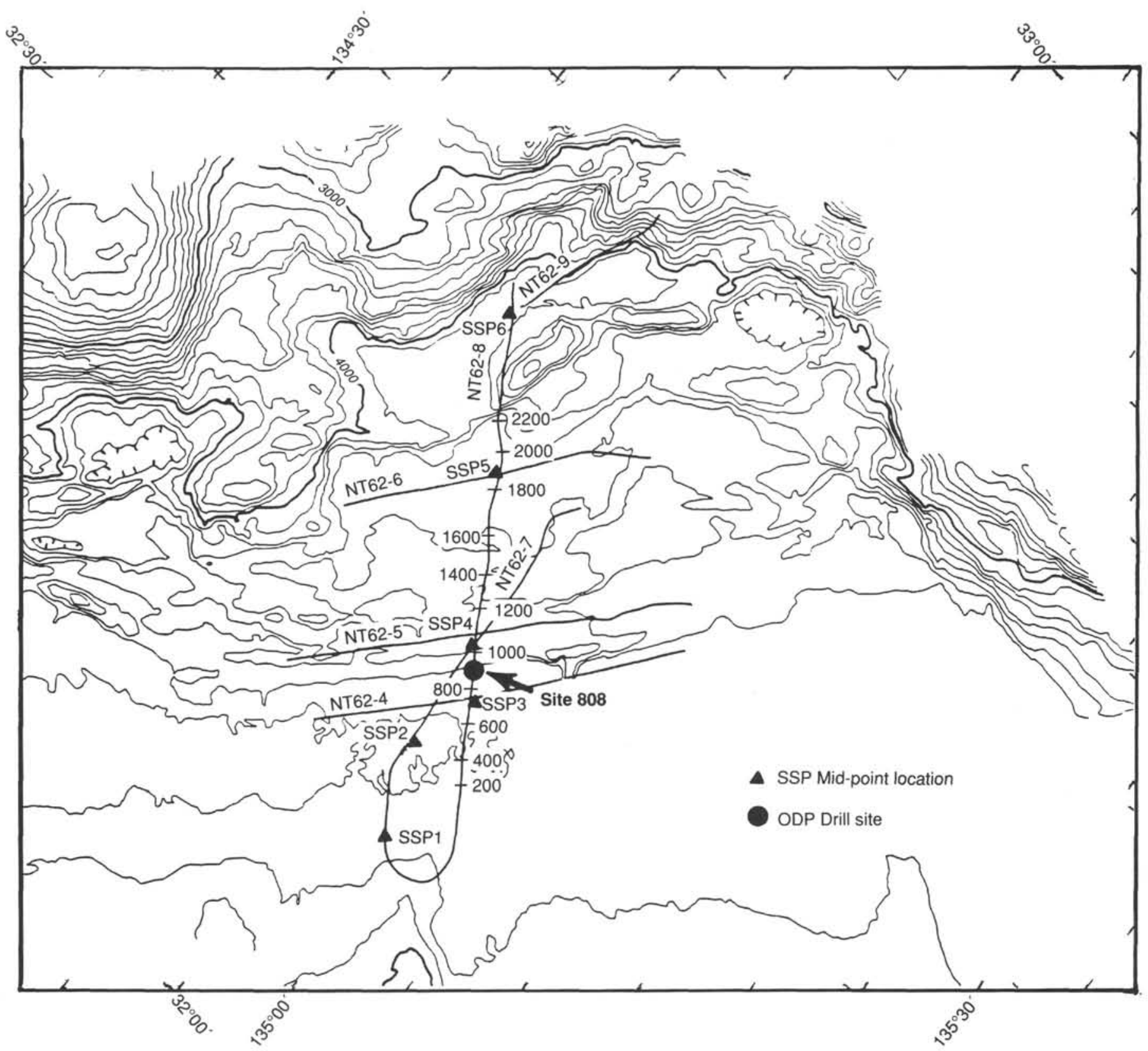

Figure 1. Regional Sea Beam bathymetric map showing location of seismic line NT62-8 and ODP Leg 131 Site 808 . Contour interval: $100 \mathrm{~m}$.

underlying basin strata in a time-transgressive facies boundary (Figs. 3 and 4; see Bray and Karig, 1988 for a detailed discussion of this boundary). This boundary merges with a strong reflection near the seaward margin of the trench (Fig. 3 ). The strong reflection correlates with the unique mudpebble conglomerate bed at about 410 mbsf in Hole $808 \mathrm{C}$ that is believed to be a debris flow deposit that flowed across the trench and onto the trench outer slope (Site 808 chapter, this volume).

The trench sedimentary section is approximately $450 \mathrm{~m}$ thick at the deformation front and thins seaward across the $12-\mathrm{km}$-wide trench floor to the outer trench slope, where it pinches out. The high-amplitude, continuous nature of the reflections from the trench strata is consistent with their origin as turbidites.

\section{STRUCTURAL GEOLOGY}

Subduction-related deformation of a scale detectable by multichannel seismic (MCS) reflection begins seaward of the base of the inner trench slope in a region designated as the "protothrust zone" (Moore et al., 1990). The zone is $2.5 \mathrm{~km}$ wide and begins at the deformation front (CMP 775 at seafloor). At the seafloor, the deformation front is marked by a subtle but sharp flexure and uplift. At greater depths, however, deformation in the form of slightly southward tilted strata extends farther to the south (to CMP 725 at $5000 \mathrm{~m}$ ). This tilt is attributed to tectonic thickening rather than to depositional effects because the direction and amount of tilt is not consonant with the latter (Karig, 1985). The trench-fill strata between CMP 850 and 875 are uplifted approximately 65 


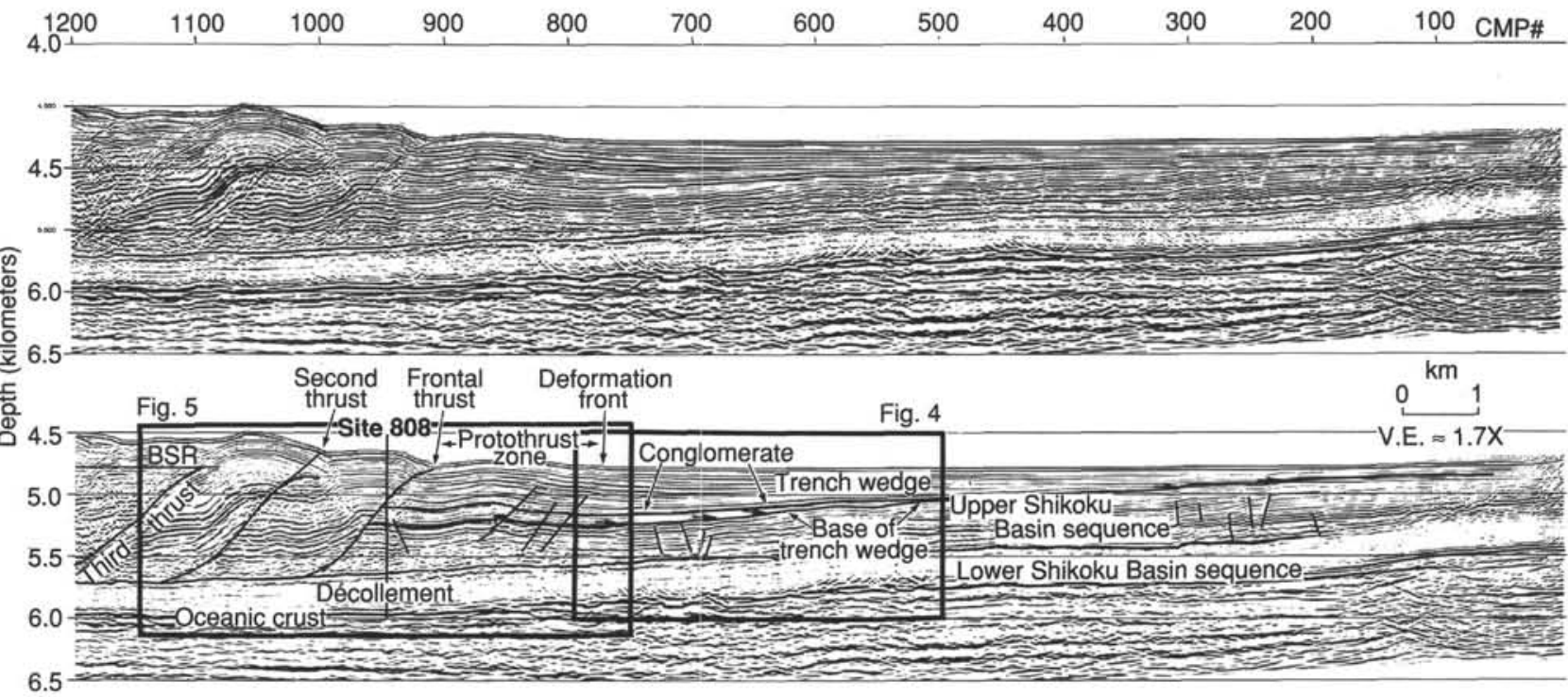

Figure 3. Depth-migrated section of seaward part of line NT62-8. Arrows indicate reflection terminations. Locations of Figures 4 and 5 are indicated with boxes.

$\mathrm{m}$ above the floor of the trench, which is a measure of the minimum tectonic thickening (see Karig, 1985, for discussion). Reflectors near the base of the trench wedge and within the hemipelagic section are offset along several landwarddipping (approximately $35^{\circ}$ ) seismic discontinuities that do not reach the seafloor, such as those imaged at about $5200 \mathrm{~m}$ at CMP 800 and at $5000 \mathrm{~m}$ at CMP 775 (Fig. 5).

The upper Shikoku Basin hemipelagic sequence is also thickened and more extensively disrupted landward of the deformation front. At the deformation front, the thickness of the sequence is approximately $225-250 \mathrm{~m}$, but this increases to more than $300 \mathrm{~m}$ at CMP 850 and to about $350 \mathrm{~m}$ at CMP 950 (Fig. 5). This increase is less than the tectonic thickening because the upper Shikoku Basin unit is thinning arcward by the facies change to trench fill (see Karig, 1985, and Bray and Karig, 1988 for clarification). It is the thickening of the Upper Shikoku Basin section that is responsible for most of the increase in dip at the deformation front. Reflector continuity within the hemipelagites is diminished landward of the deformation front, which may also be a manifestation of the structural thickening of this unit.

The lower hemipelagic layer is fairly constant in thickness from the trench landward to at least the interior of the accretionary wedge (CMP 1500; Backpocket Fig. 2). The thickness is approximately $250-270 \mathrm{~m}$ at the southeast end of the profile, with only minor variation in thickness between there and the first thrust. The layer thins to $230 \mathrm{~m}$ at the second thrust and to $210 \mathrm{~m}$ at the third thrust, but thickens again to 250 at approximately CMP 1340 . We therefore cannot define a systematic thinning of the layer as it is subducted.

The arcward boundary of the protothrust zone is marked by the first major thrust fault that extends to the seafloor and uplifts trench sediments in a hanging wall anticline. The frontal thrust is imaged as a fault-plane reflection and forms a ramp within the basin hemipelagic section (Fig. 5). The thrust is not a simple, planar feature. Although its central section is planar and dips $40^{\circ}$ (from about $5050 \mathrm{~m}$ to $5400 \mathrm{~m}$ ), its lower section is listric, intersecting the décollement with a dip of $20^{\circ}$ or less, and its upper section flattens to about $15^{\circ}$ at the seafloor. There is about $290 \mathrm{~m}$ of slip of a prominent bed along the frontal thrust. The sedimentary section of the hanging wall forms a fault-bend anticline over the ramp with a geometry that only qualitatively agrees with the fixed bedding length and constant volume models (e.g., Woodward et al., 1989). Deviations from these models are due to diffuse deformation and to volume reduction by dewatering.

The upper Shikoku Basin strata within the first thrust sheet (CMP 960-1080) are diffusely deformed, as indicated by the minor folds within these strata (e.g., 5250-5500 m at CMP 1040; Fig. 5). Structural thickening higher in the first thrust sheet is indicated by slight seaward dips of strata at about 5000 $m$ depth adjacent to the second thrust (CMP 1045), while strata at $5300 \mathrm{~m}$ (at CMP 1050) dip landward (Fig. 5).

The second thrust is also imaged as a fault plane reflection and has an overlying fault-bend fold (Figs. 3 and 5). The thrust dips about $39^{\circ}$ and has a horizontal displacement of $475 \mathrm{~m}$ and a vertical displacement of about $300 \mathrm{~m}$ (slip of $560 \mathrm{~m}$ ). The second thrust is also listric at depth and flattens at about 400 mbsf (Fig. 5, high-amplitude reflection at $4700 \mathrm{~m}$, CMP 995-1025). A splay off this thrust (beginning at $4950 \mathrm{~m}$; CMP 1035 ) cuts the hanging wall and reaches the seafloor (Figs. 3 and 5).

The spacing between imbricate thrusts at the toe of the slope is fairly regular (approximately $1.5-1.7 \mathrm{~km}$ ), but decreases slightly and systematically from the incipient thrust in the protothrust zone arcward to the third imbricate thrust. This arcward decrease can be attributed to progressive horizontal shortening within the thrust sheets. Removal of this strain produces a nearly constant initial thrust spacing that probably reflects the mechanical state.

The décollement is localized at the boundary between the upper and lower Shikoku Basin sequences and is imaged as a strong reflection into which the major thrust faults sole out. Nearly all deformation is restricted to the zone above this boundary. The décollement is imaged as a high-amplitude, reverse-polarity reflection from the north end of the profile to at least CMP 500. Although we originally interpreted this reflection as due to a single negative impedance contrast (Moore et al., 1990), the improved imaging suggests that the reflection may be generated by a finite zone with a positive impedance contrast at the top and a negative contrast at its 


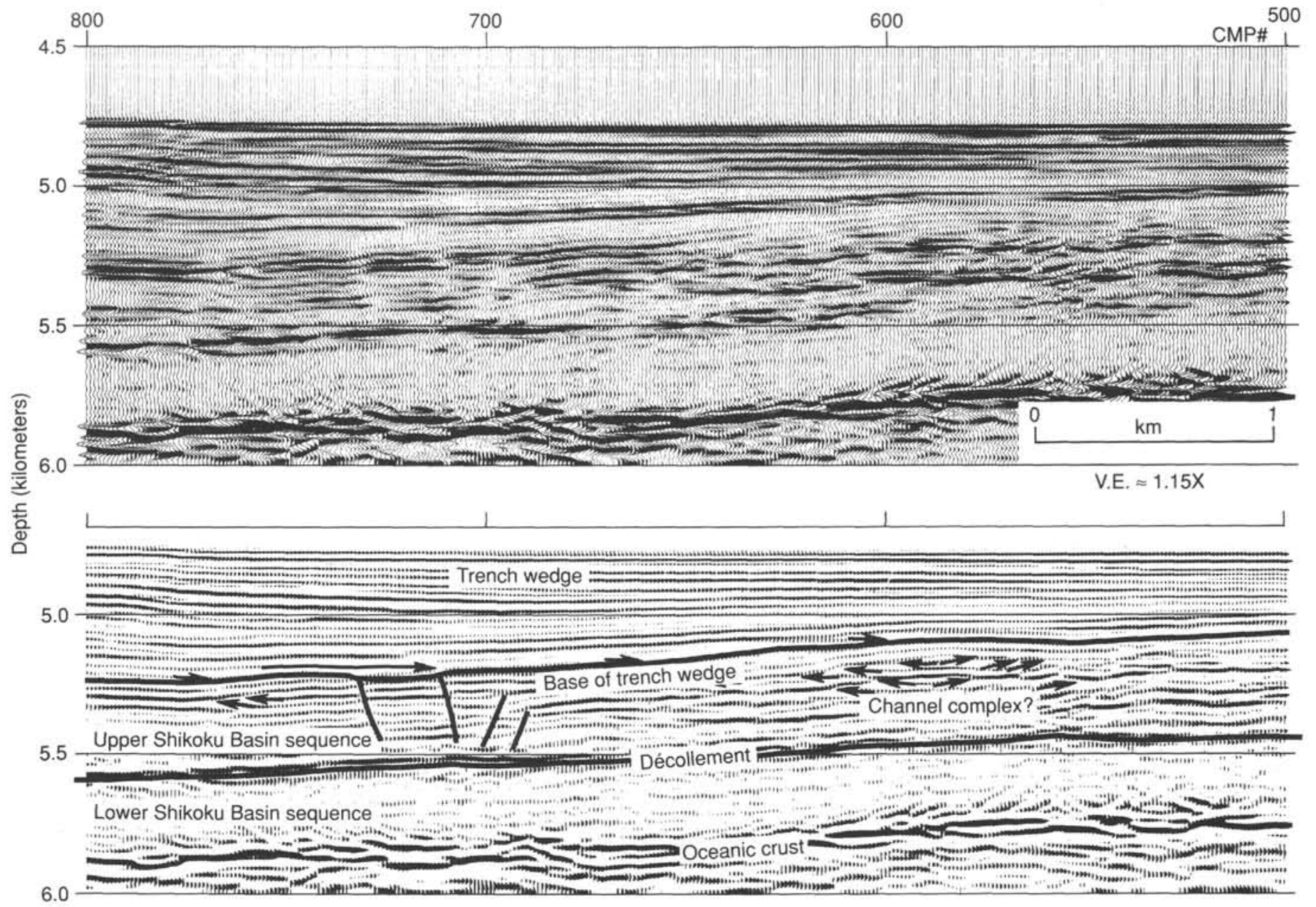

Figure 4. Detail of seismic line NT62-8 showing sedimentary features within the Shikoku Basin hemipelagic sequence. Arrows indicate reflection terminations.

base. Physical properties measurements at Site 808 substantiate this interpretation (Site 808 chapter, this volume).

The character of the décollement reflection varies in wavelength and amplitude along the profile (Figs. 3, 4, and 5). This variation may be due to changes in thickness of the zone (causing amplitude changes due to tuning effects; Schramm et al., 1977), or to changes in the velocity/density of the zone (Moore et al., 1990).

Our seismic reflection data indicate that much sediment slumps from the leading edges of the ramp anticlines. For instance, a $100-\mathrm{m}$-thick section is present at the top of the second ramp anticline (Fig. 5, CMP 1050-1065), but has been removed from both flanks of the fold. The region between the frontal thrust and the seafloor at CMP 910-935 (Fig. 5) shows a highly chaotic reflection pattern and is best interpreted as an accumulation of talus that has fallen from the front of the fold. Soft-sediment deformational structures are common in the near-surface section in Hole $808 \mathrm{~A}$, indicating that slumping of surficial sediment is an important process in this area.

\section{VELOCITY DATA}

The two-ship split-spread profiles (SSP's) show a general landward increase in velocity in most units above the décollement (Fig. 6; Stoffa et al., in press). For instance, the upper Shikoku Basin section increases in velocity from about 1.57 $\mathrm{km} / \mathrm{s}$ at SSP 1 (just seaward of the trench) to $1.92 \mathrm{~km} / \mathrm{s}$ at SSP 2 (within the trench) to $2.25 \mathrm{~km} / \mathrm{s}$ at SSP 3 (within the protothrust zone) to $2.57 \mathrm{~km} / \mathrm{s}$ at SSP4 (landward of the second thrust). This is consistent with gradual dewatering of the sedimentary section during deformation.

MCS stacking velocity analyses and SSP data indicate a velocity decrease beneath the décollement. The velocity decreases downward across the décollement from $2.27 \mathrm{~km} / \mathrm{s}$ to $2.20 \mathrm{~km} / \mathrm{s}$ in SSP 3 and from $2.0 \mathrm{~km} / \mathrm{s}$ to $1.88 \mathrm{~km} / \mathrm{s}$ in SSP 4 . SSP 2 (seaward of the décollement polarity reversal) shows a velocity increase beneath the décollement. Moreover, although the lower Shikoku Basin sequence exhibits an increase in velocity from the seaward margin of the trench to the middle of the trench, from that point landward, the unit's velocity decreases.

\section{DISCUSSION AND CONCLUSIONS}

Seismically imaged structures of the toe of the Nankai prism in the area of Leg 131 reflect a complex mechanical response to the changing stress conditions to which the sediments entering the subduction zone are subjected. These conditions include not only increases and rotations of principal stresses but also variations in pore-fluid pressures that themselves result from changes in stress and physical properties.

The underthrusting Shikoku Basin hemipelagic section does not change in thickness under the trench or lower trench slope in contrast to the pattern observed in other areas, such as off Costa Rica (Shipley and Moore, 1986). This evidence 


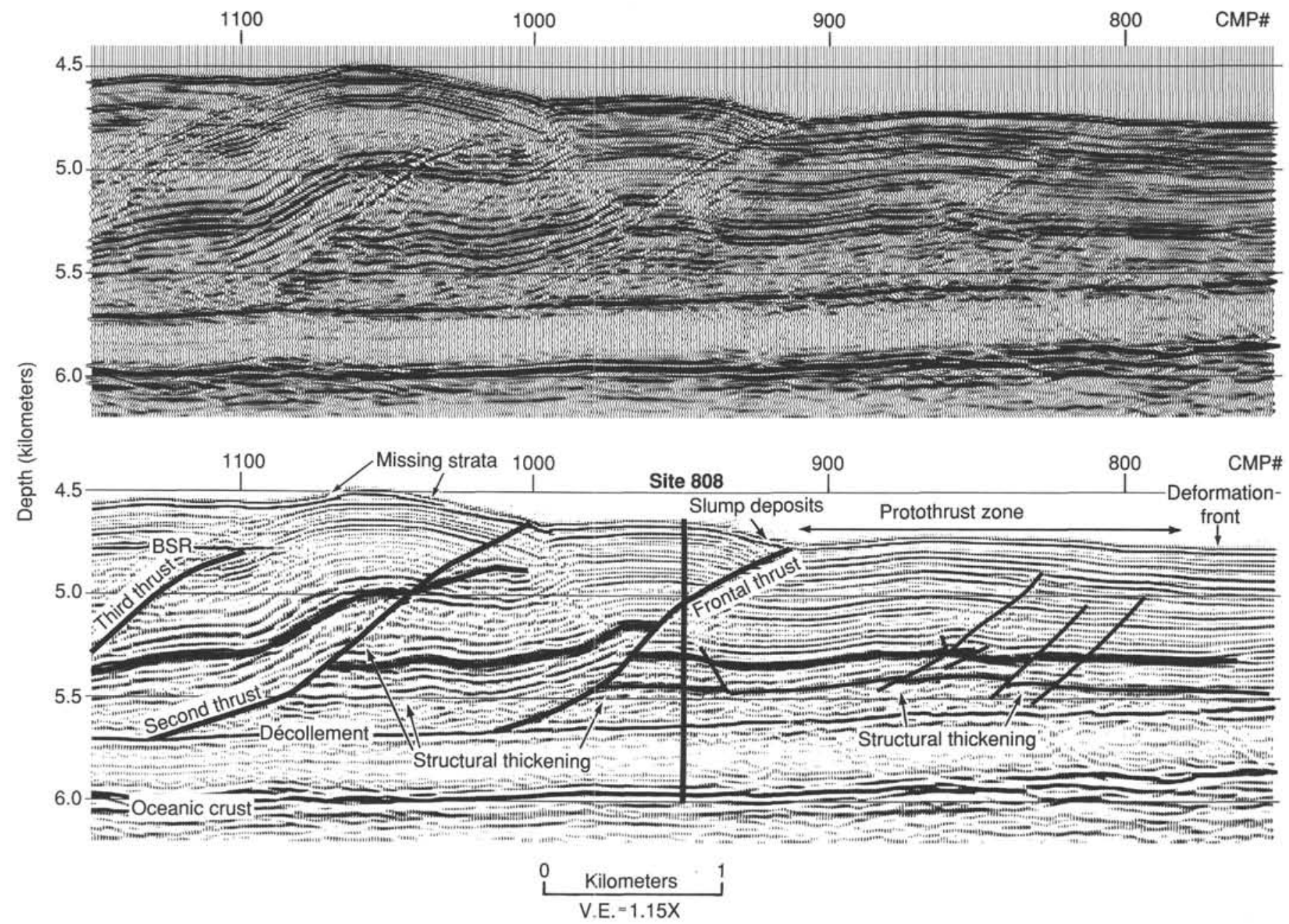

Figure 5. Detail of seismic line NT62-8 showing deformation within the protothrust and frontal thrust areas. Highlighted reflection shows slip along frontal and second thrusts.

suggests that the subducting section undergoes very little dewatering after it becomes capped by the décollement. This constancy in thickness occurs only below that section of the prism toe where the décollement is seismically imaged, which extends well seaward of the deformation front.

The seismic signature of the décollement is complex and may reflect a finite zone of high velocity. MCS and SSP velocity data as well as laboratory core velocities document a velocity inversion at the top of the underthrusting section. This downward decrease of velocity reflects a very sharp change in physical properties and mechanical state, and could result from two processes in some combination. The first is a change from high differential and effective mean stress above the décollement to a lower differential and mean stress state associated with consolidation below the décollement. The second would be inhibited dewatering below the décollement caused by restricted flow across that zone. Restriction of flow could be caused by high pore-fluid pressures within the décollement, which is consistent with the observation that the taper in this part of the toe is very small $\left(<4^{\circ}\right)$ (Moore et al., 1990).

The protothrust zone is a region of significant deformation that is dominated by layer-parallel shortening and thickening. Fluid expulsion must accompany this deformation as indicated by a general landward increase in seismic velocities (Fig. 6). Significant layer-parallel shortening also occurs in the footwalls of the major thrust packets. Because of this thickening, the section cannot be balanced using the usual assumption of bed length and/or volume conservation.

The major thrusts at the toe of the slope are imaged as high-amplitude reflections. Although it is difficult to distinguish whether the reflections are normal or reversed in polarity, the high amplitudes are unusual. These high amplitudes indicate that the thrusts are zones of sufficient thickness and sufficient impedance contrast to generate reflections. Drilling at Site 808 demonstrated that the frontal thrust is about $26 \mathrm{~m}$ thick, but poor recovery within the zone precludes accurate definition of the zone's acoustic signature.

Slumping is an important process at the toe of the Nankai prism. Large amounts of accreted sediment have been removed from the hanging wall anticlines and have been redeposited on top of lower thrust sheets and in the trench. A significant amount of the trench strata may be recycled material.

\section{ACKNOWLEDGMENTS}

This research was supported by National Science Foundation Grants OCE-8613707 and OCE-8613774. We thank M. MacKay, S. Kuramoto, and D. Dean for assistance in data processing. An earlier version was clarified by reviews by Mike Marlow and J. C. Moore. 


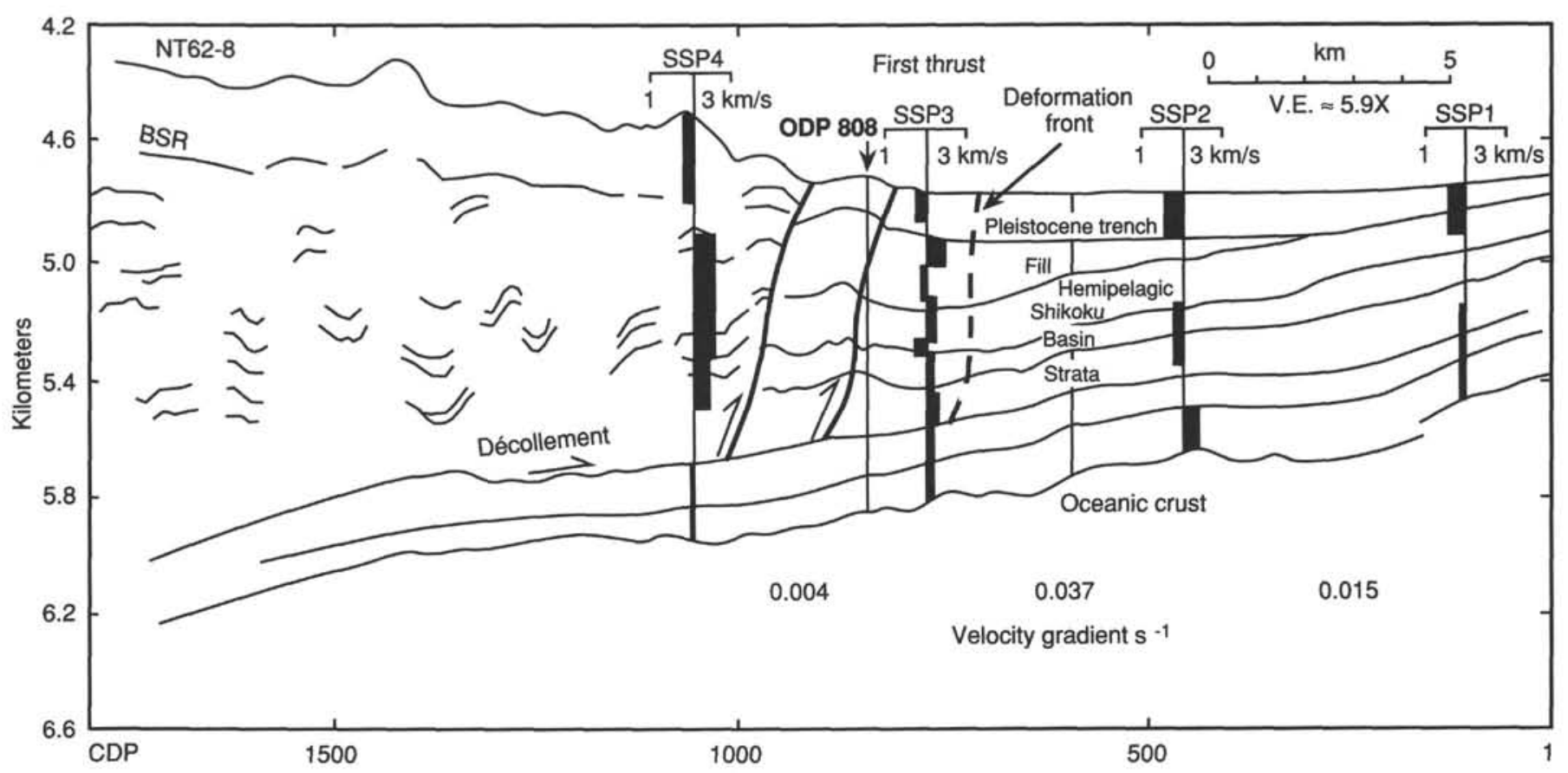

Figure 6. Summary of SSP velocity data along line NT62-8 (from Stoffa et al., in press).

\section{REFERENCES}

Bray, C. J., and Karig, D. E., 1988. Dewatering and extensional deformation of the Shikoku Basin hemipelagic sediments in the Nankai Trough. Pure Appl. Geophys., 128:725-747.

Karig, D. E., 1985. The framework of deformation in the Nankai Trough. In Kagami, N., Karig, D. E., Coulbourn, W. C., et al., Init. Repts. DSDP, 87: Washington (U.S. Govt. Printing Office) 927-940.

-, 1986. Physical properties and mechanical state of accreted sediments in the Nankai Trough, Southwest Japan Arc. Mem. Geol. Soc. Am., 66:117-133.

Karig, D. E., and Lundberg, N., 1990. Deformation bands from the toe of the Nankai accretionary prism. J. Geophys. Res., 95:90999109.

Moore, G. F., Shipley, T. H., Stoffa, P. L., Karig, D. E., Taira, A., Kuramoto, H., Tokuyama, and Suyehiro, K., 1990. Structure of the Nankai Trough accretionary zone from multichannel seismic reflection data. J. Geophys. Res., 95:8753-8765.

Schramm, M. W., Dedman, E. V., and Lindsey, J. P., 1977. Practical stratigraphic modeling and interpretation. AAPG Mem., 26:477-502.
Shipley, T. H., and Moore, G. F., 1986. Sediment accretion, subduction, and dewatering at the base of the trench slope off Costa Rica: a seismic reflection view of the decollement. J. Geophys. Res., 91:2019-2028.

Stoffa, P. L., Fokkema, J. T., de Luna Freire, R. M., and Kessinger, W. P., 1990. Split-step Fourier migration. Geophysics, 55:410412.

Stoffa, P. L., Wood, W. T., Shipley, T. H., Moore, G. F., Nishiyama, E., Bothelo, M.A.B., Taira, A., Tokuyama, H., and Suyehiro, K., in press. High resolution expanding spread and split-spread marine seismic profiles: acquisition and velocity analysis methods. $J$. Geophys. Res.

Wood, W. T., 1989. One and two-dimensional seismic velocity inversion in the domain of intercept time and ray parameter:an example in the Nankai Trough [Master's thesis]. Univ. of Texas, Austin.

Woodward, N. B., Boyer, S. E., and Suppe, J., 1989. Balance geological cross-sections. 28th Int. Geol. Congr. Short Course Notes in Geology, 6.

\section{Ms 131A-102}

